Jurnal Konstruksi Hukum | ISSN: XXXX | E-ISSN: XXXX Vol. 1, No. 1, September 2020 Hal. 109-114| Available online at https://www.ejournal.warmadewa.ac.id/index.php/jukonhum

DOI: https://doi.org/10.22225/jkh.1.1.2141.109-114

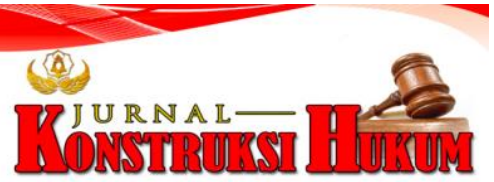

\title{
AKIBAT HUKUM TERHADAP TINDAK PIDANA PERJUDIAN BALAP LIAR DI KOTA DENPASAR
}

\author{
Gede Indra Yasa Asiawan, Anak Agung Sagung Laksmi Dewi, Luh Putu Suryani \\ Fakultas Hukum Universitas Warmadewa, Denpasar - Bali, Indonesia
}

\begin{abstract}
Abstrak
Setiap warga negara memiliki sifat dan keinginan yang berbeda-beda setiap harinya, tidak terkecuali masyarakat di Indonesiaa mulai dari usia belia sampai lanjut usia memiliki ambisi yang variatif dalam hidup, dan bertindak. Perilaku masing-masing individu demi mencapai tujuan beraneka ragam, mulai dari hobi sampai cara menjalani hidup yang tentu dibatasi oleh peraturan pemerintah yang mengharuskan seseorang mematuhi hukum positif yang berlaku saat ini. Penelitian ini membahas tentang pengaturan tindak pidana perjudian balap liar di Kota Denpasar dan apa sanksi terhadap tindak pidana balap motor liar di Kota Denpasar. Metode yang digunakan dalam penelitian ini adalah tipe penelitian hukum normatif yang dilakukan dengan metode pencatatan dan pengkajian berdasarkan bahan - bahan hukum. Hasil penelitian ini menunjukkan bahwa pengaturan tindak pidana untuk perbuatan yang dilakukan oleh remaja dalam aksi balapan liar belum diatur dalam peraturan khusus tetapi perbuatan yang dilakukan oleh remaja tersebut sudah melanggar ketentuan UU No. 22 tahun 2009, sedangkan hasil akhir dari pemberian sanksi yang diberikan pihak kepolisian terhadap perjudian balapan liar tidak begitu efektif, dikarenakan sanksi hanya berupa peringatan kemudian dipanggil orang tuanya masing-masing, apabila kedapatan melakukan lagi atau masih ada yang melakukannya dan mendapat perbuatan yang sama maka kendaraan mereka ditilang atau ditahan. Adapun perlindungan hukum preventif mengenai pencegahan sudah dilakukan tidak hanya dari pihak kepolisian saja, akan tetapi dari pihak masyarakat, kepala desa atau perangkat desa dan khususnya orang tua yang anaknya terlibat dalam kelompok ini, yang lebih berkontribusi dalam mengatasi dan mencegah supaya dikemudian hari jangan terulang perbuatan yang melanggar hukum.
\end{abstract}

Kata kunci: Balap Liar; Perjudian; Tindak pidana

\begin{abstract}
Every citizen has different characteristics and desires every day including Indonesian citizens from young people to old ones have varied ambitions in life and action. The behavior of each individual in order to achieve various goals, either hobbies or ways of living life which is also limited by government regulations that require a person to obey the current positive laws. This research discusses how the regulation of gambling of illegal racing in Denpasar City and how the effect of consequences of gambling of illegal racing in Denpasar City. The method used in this research is a type of normative legal research which is carried out by the method of recording and reviewing legal materials. The results of this study indicate that the regulation of criminal acts committed by adolescents in illegal racing has not been regulated in certain regulations, but the acts committed by these teenagers have violated the provision of Law No. 22 of 2009, while the final result of the sanctions imposed by the police on gambling of illegal racing is not very effective, because the sanctions are only in the form of warnings and then called by their respective parents, if they are caught doing it again or someone is still doing it and gets the same act then their vehicle is ticketed or detained. As for preventive legal protection regarding prevention, it has been carried out not only from the police, but from the community, village heads or village officials and especially parents whose children are involved in this group, who contribute more in overcoming and preventing future actions that breaks the law.
\end{abstract}

Keywords: Illegal Racing; Gambling; Crime

\section{PENDAHULUAN}

Tingkah laku setiap orang berbeda demi mencapai kebahagiaan dan tujuan mereka, setiap langkah yang diambil sudah dipikirkan terlebih dahulu agar mencapai kesuksesan, perbuatan masyarakat tidak selamanya merupakan perbuatan yang membuat lingkungan dan orang disekitarnya senang dan tidak semua perbuatan didasari dari hati nurani dan keinginan sendiri. Tidak sedikit perbuatan masyarakat dipengaruhi oleh orang lain atau mencontoh suatu perbuatan yang dimata 
seorang terlihat sebagai perbuatan benar dan wajib dilakukan namun nyatanya berbeda dari kenyataan. Seiring berkembangnya waktu, segala sesuatu semakin mudah dilakukan semisal perbuatan yang didasari atas norma dan banyak perbuatan yang melanggar peraturan yang berlaku. Semua dilakukan atas dasar rasa ingin tahu namun jika keingintahuan tidak didasari pemikiran jernih akan timbul masalah dikemudian hari yang menyebabkan kerugian bagi diri sendiri, lingkungan dan orang terdekatnya. Kebanyakan perilaku menyimpang dari norma dilakukan anak di masa menuju dewasa atau remaja, rasa ingin tahu yang tinggi membuat segala sesuatu dilakukan tanpa pemikiran matang dan tidak memikirkan efek samping dari perbuatannya (Baharudin et al., 2019). Perbuatan seseorang erat kaitannya dengan hobi yang dijalani namun banyak yang menyimpang dari peraturan pemerintah semisal hobi balapan motor, sebenarnya tidak ada yang salah dengan hobi tersebut melainkan pelaksanaan adu kebisaan para remaja ini tidak pada tempatnya di lapangan balap motor namun dilakukan di jalan umum yang dapat menyebabkan segala pengguna jalan lain menjadi resah dan terjadi secara ugal-ugalan (Yuliartini, 2017).

Di Indonesia sendiri sudah tidak terhitung banyaknya anak muda yang melakukan aksi balap motor di jalan umum, bagaikan kecanduan dengan balapan membuat seorang remaja mengesampingkan keselamatan hidup mereka dan lebih memilih terkenal dengan kebodohan yang dilakukan dengan memacu kencang kendaraan mereka (Rosanti \& Fuad, 2015). Kejadian ini sebernarnya dipicu pola pikir yang masih labil atau emosi yang susah dikendalikan, sehingga membuat para remaja buta akan peraturan pemerintah dengan norma dan sanksi yang diberikan bagi para pelanggar hukum. Dapat dipastikan bahwa tindakan melanggar peraturan lalu lintas merupakan pelanggaran hukum yang berbuah hukuman bagi para pelanggarnya, jangankan balapan liar seorang murid terlambat hadir pada jam pelaran pun pasti mendapatkan hukuman atas keterlambatannya (Kartono, 1997).

Tidak bisa menyalahkan begitu saja hobi tersebut namun tidak terarah dengan benar merupakan keteledoran dalam pola pikir seseorang. Pergaulan bebas menjadi salah satu faktor penyebab seorang dengan tanpa memikirkan aturan hukum yang ada melakukan tindakan dengan begitu bebas dan menyepelekan hukuman yang dibuat pemerintah bagi siapa saja dengan sengaja melanggar hokum (Sumara et al., 2017). Pergaulan bebas dapat menciptakan komplotan atau bahasa kerennya "Geng" yang semakin membuat meluap - luap ego seseorang dalam bertindak yang artinya setiap tindakan yang dilakukan secara bersama - sama dengan komplotan tidak membuat menjadi lemah dalam bergaul dan merasa cukup hebat dengan dirinya serta merasa mampu memiliki apapun yang ada di lingkungan mereka tetapi keadaan tersebut membuat kemunduran akal sehat seseorang yang bisa berakibat depresi bahkan sampai gila jika salah satu keinginannya tidak tercapai. Banyak orang mengatakan buah tidak jatuh jauh dari pohonnya merupakan pribahasa kuno yang dibuat nenek moyang karena saat masa nenek moyang semua keadaan harmonis tanpa ada alat komunikasi dan teknologi secanggih sekarang yang setiap saat bisa membuat ego seseorang menjadi berubah tanpa kecuali para remaja.

Indonesia memiliki peraturan yang melarang siapa saja tanpa kecuali melakukan tindakan kekerasan semisal pencurian, pelecehan sampai pembunuhan, meski seseorang memiliki HAM tidak semata - mata secara langgung melindungi seorang dari jerat hukum yang berlaku. Salah satu perbuatan melanggar hukum sering terjadi di Indonesia yaitu balap liar dimana pelaku atau pemainnya berusia remaja dengan ego yang masih berapi-api dan pemikiran pendek. Pemerintah menetapkan Undang - Undang Pidana pasal 303 yang berisi larangan melakukan perbuatan judi yang membebani pelaku dengan sanksi berat. Aturan tersebut juga berlaku bagi para pembalap liar yang biasanya mempertaruhkan sejumlah uang sebagai hadiah bagi kendaraan tercepat sampai garis finis dan lainnya. Melihat kian marak balapan liar yang ada membuat pihak kepolisian sebagai garda terdepan Negara dalam menjaga ketertiban dan keamanan masyarakat menjadi geram dan rutin mengadakan penjagaan serta memantau aktivitas para geng motor sesaat sebelum beraksi (Putu \& Yuliartini, 2014). Tujuan dibentuknya kepolisian sebagai pemutus tindakan melanggar hukum salah satunya balapan liar yang rutin dilakukan para anak saat beranjak dewasa. Bentuk kepedulian polisi kepada masyarakat menciptakan suasana aman tentram bagi masyarakat agar selalu merasa nyaman saat berada diluar rumah serta memberikan pelayanan 24 jam sehari jika ada pengaduan dari masyarakat yang mengalami suatu perbuatan pelecehan atau sejenisnya. 
Berdasarkan penjelasan diatas, makan penelitian ini bertujuan untuk mengetahui pengaturan tindak pidana perjudian balap liar di Kota Denpasar, dan apa sanksi terhadap tindak pidana balap motor liar di Kota Denpasar.

\section{METODE PENELITIAN}

Penelitian ini dilaksanakan dengan menggunakan metode normatif dan kualitatis dimana dalam pengerjaannya ditelaah isu hukum dengan didasari peraturan - peraturan hukum Pidana yang berlaku di Indonesia (Ahmad, 2008). Penelitian hukum normatif adalah hukum kepustakaan yang mengacu pada norma hukum yang terdapat dalam peraturan Perundang-undangan (Waluyo, 2002). Pencarian informasi secara normatif berpatokan pada peraturan pemerintah yang berfokus pada balap Liar sebagai objeknya dan analisis dalam informasi yang didapat secara konseptual berkaitan dengan penulisan ini.

Pendekatan perundangan - undangan adalah melakukan suatu penelitian dengan berpatokan pada undang - undang sebagai dasar pelaksanaan penelitian. Pendekatan kasus dilakukan guna melihat, mencatat dan memahami permasalahan yang diangkat dalam penelitian dengan tidak keluar dari zona hukum positif.

\section{HASIL DAN PEMBAHASAN}

\section{Pengaturan Tindak Pidana Perjudian Balap Liar di Kota Denpasar}

Balap motor salah satu orahraga atau hobi yang memiliki banyak pecinta dan tidak melanggar peraturan apapun selama penyelenggaraanya jelas dan memiliki ijin dalam penyelenggarannya. Sering kali atraksi yang disajikan saat pertandingan menjadi inspirasi bagi banyak remaja namun salah saat mengaplikasikannya. Balap liar merupakan wujud ketidakpuasan para remaja dalam menjalani hidup, alasan seseorang balap liar disamping akibat pergaulan juga tempat mencari perhatian atau sensasi, kebisingan yang ditimbulkan saat semua remaja berkumpul untuk melakukan perjudian adu kecepatan membuat banyak masyarakat menjadi takut melakukan kegiatan diluar rumah pada malam hari, selain membuat resah aksi para remaja berkumpul pada malam hari seakan tidak mengenal rasa takut keadilan yang ditegakkan di Indonesia. Dana yang dikeluarkan sebagai hadiah bagi pemenang balapan liar pun tidak sedikit, mirip dengan sabung ayam yang menonton juga dapat melakukan judi dengan mempertaruhkan uang pada salah satu peserta balap liar. Kendaraan yang digunakan para remaja ketika balapan liar sudah dimodifikasi secara total dan menghabiskan dana tidak sedikit mulai dari kepala sampai mesin motor diatur sedemikian rupa demi menjaga nama atau gengsi. Semakin banyak uang dihabiskan untuk memodifikasi kendaraan, maka kepercayaan diri para pelaku balap liar semakin tinggi. Saat rasa ingin tahu remaja semakin tinggi, semakin tidak masuk akal hal yang mereka lakukan sampai akhirnya sadar bahwa usia tidak selamanya muda. Balap liar sering dilakukan saat kondisi jalan umum sepi semisal waktu te $\mathrm{ng}$ a $\mathrm{h}$ malam sampai subuh dan berlangsung salama berulang - ulang sampai saat pihak kepolisian memergoki kegiatan balap liar barulah tempat berkumpul berubah (Anwar, 2009).

Mahirnya remaja dalam mengendarai kendaraan sedikit tidaknya berpengaruh dalam balapan liar yang marak terjadi, sebagaian dari mereka menganggap jalan umum persis dengan sirkuit balapan dan pengendara lain sebagai rintangan yang harus dilewati demi meraih sebuah kemenangan. Tidak jarang terjadi kecelakaan lalu lintas akibat ulah balap liar remaja milenial, seakan nyawa bukan menjadi yang terpenting melainkan gengsi harga mati. Terkenalnya balapan liar dikarenakan setiap kendaraan yang tampil sudah berisikan joki secara tidak langsung sebagai pilot namun bukan pemilik kendaraan, tugas pemilik hanya merubah kecepatan dan menambah laju motor yang memudahkan joki meraih kemenangan. Faktor berubahnya kecepatan kendaraan balap liar membuat polisi sulit menangkap para remaja, seringnya melarikan diri saat penangkapan membuat kejar - kejaran berakhir tanpa hasil atau sangat jarang polisi bisa menangkap para remaja balap liar. Peningkatkan kecepatan kendaraan diatas rata - rata memerlukan biaya besar, seorang pelajar tidak mungkin memiliki uang sebanyak itu ketika masih bersekolah bisa saja mereka meminta pada orang tua dengan alasan membeli keperluan sekolah atau membayar biasa sekolah dan yang terparah melakukan perbuatan mencuri milik orang lain, jelas perbuatan melanggar hukum tapi tidak menutup kemungkinan pemikiran itu terjadi.

Nilai rupiah bagi pemenang balapan cukup besar membuat para remaja tertarik mengikuti balap liar dan melakukan banyak cara agar menang seperti meningkatkan dapur pacu motor, 
bodohnya lagi kegiatan illegal ini mendapatkan antusias dari para remaja sebaya lainnya mereka berkumpul layaknya setelah ada pemenang mereka menyaksikan sejarah baru yang dapat merubah dunia dalam sekejap. Konflik tidak terhindarkan terjadi saat mendapatkan pemenang balapan pihak yang kalah tidak terima dan terjadi baku hantam berakhir babak belur bahkan sampai meninggalkan korban jika, hal ini yang sudah ditakuti para kepolisian nyawa terbuang sia-sia hanya karena mengikuti ego tanpa mempertimbangkan resiko yang menanti (Darajat, 1985).

Ajang mendekatkan diri pada Tuhan ini kian hari kian banyak peminatnya karena tergiur hadiah balapan yang nilainya besar. Terdapat beberapa komponen dari kegiatan para remaja yaitu:

1. Seorang dengan skil mengandalikan setiap kendaraan yang sudah dimodifikasi, di bawa oleh pemilik kedaraan atau dari tempat perbaikan motor yang digunakan balap liar dikatakan sebagai joki.

2. Kendaraan dengan tampilan standar namun secara tidak langsung sudah dimodifikasi sedemikian rupa sebagai mesin pencetak uang dengan memenangkan setiap balapan yang dilakukan disebut kendaraan pembalap liar

3. Tidak bisa ditutupi bahwa nominal dari pemenang balapan liar tidak sedikit bahkan setara dengan hasil perubahan kecepatan motor pembalap yang membuat seorang remaja tidak ragu merubah keadaan motornya namun resiko yang dihasilkan tidak dapat dibandingkan dengan banyak uang didapat setelah memenangkan balap liar.

4. Saling memberikan hasil maksimal antar para pemilik bengkel agar para remaja datang dan memodifikasi kendaraan mereka ditambah jika motor yang sudah dimodifikasi menang dalam balapan membuat nama bengkel semakin dikenal para remaja.

5. Banyaknya antusias remaja lain untuk menonton balapan menjadi daya Tarik tersendiri ditambah banyak diantara kumpulan penonton berjenis kelamin wanita semakin membuat remaja ingin mengadakan balap liar setiap saat.

Kondisi sulit ini dihadapkan kepada para penegak hukum khususnya kepolisian. Semakin ingin menangkap para pembalap liar maka semakin pintar para remaja melarikan diri. Beberapa faktor yang membuat balapan liar begitu terkenal dikalangan remaja keadaaan jalanan sepi dimanfaatkan sebagai arena balap, para remaja berada di tingkat emosi meledak - ledak sehingga sering melupakan resiko dari perbuatan yang dilakukan terlebih diikuti banyak orang membuat pola pikir tidak matang, besar hadiah bagi pemenang membuat remaja berambisi menang dan menang namun melupakan tujuan mereka sekolah menuntut ilmu, kurang perhatian keluarga membuat seorang remaja mengambil jalan pintas dengan menjadi pembalap liar untuk mendapatkan pengakuan orang banyak atau agar terkenal sehingga bisa dihormati dan memiliki banyak perhatian yang didapat dari orang lain yang pada akhirnya orang tuanya menyadari kehebatan dirinya sebagai seorang pembalap liar, selalu menang disetiap pertandingan membuat bakat alami menjadi sia-sia karena balapan liar merupakan balapan ilegal yang bagi sebagian besar masyarakat para pembalap liar setara dengan seorang criminal yang harus dihukum atas perbuatannya.

Mengantisipasi berlanjutnya kegiatan balap liar pihak kepolisian mengadakan pemeriksaan surat kendaraan secara rutin ditempat yang selalu berpindah - pindah, membuat para pelaku balap liar tidak bisa membaca gerak - gerik kepolisian dalam memutus rantai balapan liar. Banyak kendaraan yang digunakan para pembalap liar dengan surat - surat palsu yang artinya secara kasat mata kondisi kendaraan sama seperti kondisi standarnya namun kecepatan yang dihasilkan kendaraan yang biasa dipakai balapan liar berbeda dari surat kendaraannya bisa membuat seorang ditinggal dengan tuduhan pemalsuan surat kendaraan bermotor. Tanggung jawab orang tua dalam memantau, memberikan edukasi dan pendidikan serta perhatian kepada seorang anak yang beranjak dewasa sangat penting karena jika tidak diarahkan seorang bisa dengan kemauannya sendiri mengikuti naluri yang didapat dari pergaulan bebas membuat seorang remaja melakukan kegiatan yang melanggar norma dan ketentuan hukum positif membuat mereka menjadi target hukum sebagai pelaku tindak kejahatan.

Di Indonesia terdapat peraturan yang mengatur mengenai perjudian, seperti yang diatur dalam Pasal 303 Kitab Undang-Undang Hukum Pidana dan untuk perjudian online diatur dalam Pasal 27 ayat (2) Undang-Undang Nomor 11 Tahun 2008 tentang Informasi dan Transaksi Elektronik(UU ITE) sebagaimana yang telah diubah oleh Undang-Undang Nomor 19 Tahun 2016 tentang Perubahan Atas Undang-Undang Nomor 11 Tahun 2008 tentang Informasi dan Transaksi Elektronik (UU 19/2016). Jalanan umum di buat untuk seluruh warga Negara tanpa membedakan ras dan budaya semua kalangan bebas melakukan perjalanan melalui jalan umum sesuai 
peraturan pemerintah namun tidak semua orang dapat mentaati peraturan yang sudah jelas pengertian bahkan sanksi yang di dapat bagi yang melanggar peraturan. Melalui materi pembelajaran para guru dan pihak terkait memberikan pembelajaran tentang bahayanya balapan liar dan sanksi jika melanggar aturan yang di buat pemerintah.

\section{Sanksi terhadap Tindak Pidana Balap Motor Liar di Kota Denpasar}

Di Indonesia terdapat peraturan yang mengatur mengenai perjudian, seperti yang diatur dalam Pasal 303 Kitab Undang-Undang Hukum Pidana dan untuk perjudian online diatur dalam Pasal 27 ayat (2) Undang-Undang Nomor 11 Tahun 2008 tentang Informasi dan Transaksi Elektronik (UU ITE) sebagaimana yang telah diubah oleh Undang-Undang Nomor 19 Tahun 2016 tentang Perubahan Atas Undang-Undang Nomor 11 Tahun 2008 tentang Informasi dan Transaksi Elektronik (UU 19/2016). Pasal 303 bis ayat (1) KUHP, berbunyi:

Diancam dengan kurungan paling lama 4 (empat) tahun atau denda paling banyak sepuluh juta rupiah:

1. barangsiapa menggunakan kesempatan untuk main judi, yang diadakan dengan melanggar peraturan pasal 303

2. barangsiapa ikut serta permainan judi yang diadakan di jalan umum atau di pinggirnya maupun di tempat yang dapat dimasuki oleh khalayak umum, kecuali jika untuk mengadakan itu, ada izin dari penguasa yang berwenang.

Sementara itu mengenai perjudian online diatur dalam Pasal 27 ayat (2) UU ITE yang berbunyi "Setiap Orang dengan sengaja dan tanpa hak mendistribusikan, mentransmisikan, dan/atau membuat dapat diaksesnya Informasi atau Dokumen Elektronik yang memiliki muatan perjudian". Ancaman terhadap pelanggaran ini diatur dalam Pasal 45 ayat (2) UU 19/2016, yakni : "Setiap Orang yang dengan sengaja dan tanpa hak mendistribusikan dan/atau mentransmisikan dan/atau membuat dapat diaksesnya Informasi Elektronik dan/atau Dokumen Elektronik yang memiliki muatan perjudian sebagaimana dimaksud dalam Pasal 27 ayat (2) dipidana dengan pidana penjara paling lama 6 (enam) tahun dan/atau denda paling banyak Rp 1 miliar".

Dalam ilmu hukum ada perbedaan antara istilah "pidana" dengan istilah "hukuman". istilah hukuman yang merupakan istilah umum dan konvesional, dapat mempunyai arti yang luas dan berubah-rubah karena istilah tersebut dapat berkonotasi dengan bidang yang cukup luas. Istilah tersebut tidak hanya sering digunakan dalam bidang hukum, tetapi juga dalam istilah sehari-hari dibidang pendidikan, moral, agama dan sebagainya. Oleh karena itu pidana merupakan istilah yang lebih khusus, maka perlu ada pembatasan pengertian atau makna sentral yang dapat menunjukkan ciri-ciri dan sifat-sifatnya yang khas. Pengertian tindak pidana yang dimuat didalam Kitab Undangundang Hukum Pidana (KUHP) oleh pembentuk undang-undang sering disebut dengan strafbaar feit. Para pembentuk undang- undang tersebut tidak memberikan penjelasan lebih lanjut mengenai strafbaar feit.

Oleh karena itu, maksud, tujuan serta makna strafbaar feit sering dipergunakan oleh pakar hukum pidana dengan istilah tindak pidana, perbuatan pidana, peristiwa pidana, dan serta delik pidana 27. Moeljatno (1987) menyatakan bahwa "pengertian tindak pidana berarti perbuatan yang dilarang dan diancam dengan pidana, terhadap siapa saja yang melanggar larangan tersebut. Perbuatan tersebut harus juga dirasakan oleh masyarakat sebagai suatu hambatan tata pergaulan yang dicita-citakan oleh masyarakat".

Pelanggaran terhadap ketertiban umum pada buku ketiga KUHP tidak dijelaskan mengenai arti pelanggaran itu sendiri. Pelanggaran dapat dibedakan dengan kejahatan melalui sanksi yang diberikan. Sanksi yang diberikan bagi pelaku pelanggaran umumnya lebih ringan dari pada pelaku kejahatan. Pelanggaran adalah delik undang-undang (wetsdelicten) yaitu perbuatan yang sifat melawan hukumnya baru dapat diketahui setelah adanya undang - undang yang mengaturnya.

Maka suatu tindakan telah melanggar apabila hakikat dari perubahan itu menimbulkan adanya sifat melawan hukum dan telah ada aturan atau telah ada undang-undang yang mengaturnya. Walaupun perbuatan itu telah menimbulkan suatu sifat melawan hukum namun belum dapat dinyatakan sebagai suatu bentuk pelanggaran sebelum diatur dalam perundang-undangan.

Maka suatu tindakan telah melanggar apabila hakikat dari perubahan itu menimbulkan adanya sifat melawan hukum dan telah ada aturan atau telah ada undang-undang yang mengaturnya. Walaupun perbuatan itu telah menimbulkan suatu sifat melawan hukum namun belum dapat 
dinyatakan sebagai suatu bentuk pelanggaran sebelum diatur dalam perundang-undangan. Pidana (KUHP) karena mengganggu ketentraman masyarakat dimalam hari oleh suara berisik dari knalpot motor para pelaku.

\section{SIMPULAN DAN SARAN}

\section{Simpulan}

Berdasarkan hasil analisis penelitian di atas, maka dapat disimpulkan bahwa pengaturan tindak pidana untuk perbuatan yang dilakukan oleh remaja dalam aksi balapan liar belum diatur dalam peraturan khusus tetapi perbuatan yang dilakukan oleh remaja tersebut sudah melanggar ketentuan UU No. 22 tahun 2009, sedangkan perlindungan hukum preventif mengenai pencegahan sudah dilakukan tidak hanya dari pihak kepolisian saja, akan tetapi dari pihak masyarakat, kepala desa atau perangkat desa dan khususnya orang tua yang anaknya terlibat dalam kelompok ini, yang lebih berkontribusi dalam mengatasi dan mencegah supaya dikemudian hari jangan terulang perbuatan yang melanggar hukum. Kemudian, penerapan sanksi yang diberikan pihak kepolisian terhadap balapan liar tidak begitu efektif, dikarenakan sanksi hanya berupa peringatan kemudian dipanggil orang tuanya masing-masing, apabila kedapatan melakukan lagi atau masih ada yang melakukannya dan mendapat perbuatan yang sama maka kendaraan mereka ditilang atau ditahan. Perjudian merupakan perbuatan yang melanggar hukum positif di Indonesia para penjudi dapat dikenakan sanksi pidana 6 bulan dengan denda paling banyak 1 Miliyar rupiah sesuai dengan Undang - Undang Nomor 19 Tahun 2016. Sesuai dengan ketentuan Undang-Undang Lalu Lintas dan Angkutan Jalan, di dalam pasal Pasal 287 Ayat 5, Pasal 287 Ayat 6, Pasal 297, dan Pasal 311 Ayat 1 bahwa apabila perbuatan yang melanggar aturan bagi pengendaraan maka dikenakan sanksi denda dan penjara kurungan paling lama 1 (satu) tahun, oleh karena sanksi yang diberikan tidak begitu relevan sehingga membuat hukuman tidak begitu efektif terhadap pelaku balap liar.

\section{Saran}

Melalui penelitian ini, diharapkan kepada orang tua supaya memberikan pembelajaran kepada anak tentang bahaya balap liar dan akibat hukum bila kedapatan melakukan balap liar serta pihak kepolisian wajib memberi peringatan tegas bagi usia remaja serta memberikan sosialisasi agar nantinya mereka tidak melakukan tindakan - tindakan yang menyebabkan terjadinya gangguan ketertiban di jalan raya. Pihak kepolisian diharuskan mampu mengupayakan budaya sadar berkendaraan yang baik dan benar. Untuk mewujudkan ketertiban di jalan raya, tidak hanya tugas kepolisian, melainkan juga menjadi tugas semua orang.

\section{DAFTAR PUSTAKA}

Ahmad, B. (2008). Metode Penelitian Hukum. Pustakasetia.

Anwar, Y. (2009). Saat Menuai Kejahatan (Sebuah Pendekatan Sosiokultural Kriminologi, Hukum, dan HAM). PT. Refika Aditama.

Baharudin, P., Zakarias, J. D., \& Lumintang, J. (2019). Faktor-Faktor yang Mempengaruhi Tingkat Kenakalan Remaja (Suatu Studi di Kelurahan Kombos Barat Kecamatan Singkil Kota Manado). HOLISTIK, Journal Of Social and Culture, 12(3).

Darajat, Z. (1985). Faktor-faktor yang Merupakan Masalah dalam Proses Pembinaan Generasi Muda. Bina Cipta.

Kartono, K. (1997). Patologi Sosial 3 (Gangguan-Gangguan Kejiwaan). PT. Raja Grafindo Persada. Moeljatno. (1987). Asas-Asas Hukum Pidana. Bina Aksara.

Putu, N., \& Yuliartini, R. (2014). Kajian Kriminologis Kenakalan Anak dalam Fenomena Balapan Liar di Wilayah Hukum Polres Buleleng. 7(3), 395-410.

Rosanti, A., \& Fuad, F. (2015). Budaya Hukum Balap Liar di Ibukota. Lex Jurnalica, 12(1), 65-78.

Sumara, D., Humaedi, S., \& Santoso, M. B. (2017). Kenakalan Remaja dan Penanganannya. Jurnal Penelitian \& PPM, 4(2).

Waluyo, B. (2002). Penelitian Hukum Praktek. Sinar Grafika.

Yuliartini, N. P. R. (2017). Penanggulangan Balapan Liar Melalui Diseminasi Undang-Undang Nomor 22 Tahun 2009 tentang Lalu Lintas dan Angkutan Jalan di Kalangan Remaja Kota. 6(2), $81-89$. 